\title{
A molecular phylogeny of Geotrochus and Trochomorpha species (Gastropoda: Trochomorphidae) in Sabah, Malaysia reveals convergent evolution of shell morphology driven by environmental influences
}

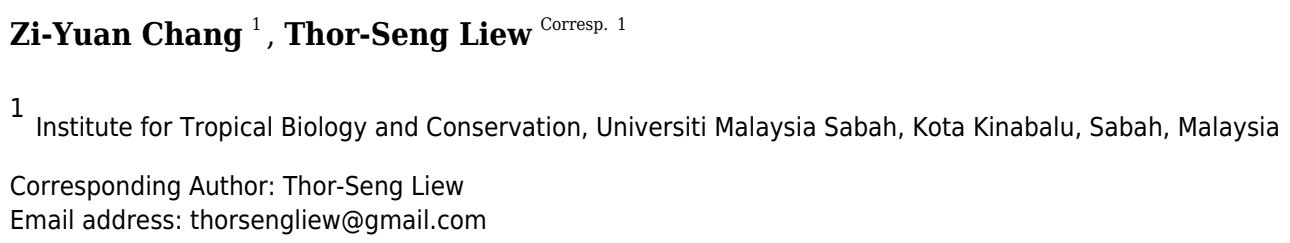

There are currently eleven Geotrochus and four Trochomorpha species in Sabah. The primary diagnostic character that separates the two genera is the intensity of sculpture on the shell upper surface. All Trochomorpha species have a coarse nodular sculpture while Geotrochus species has a non-nodular sculpture or smooth shell. However, it is known that shell characters are often evolutionary labile with high plasticity in response to environmental factors. Hence, identifying the phylogenetic and ecological determinants for the shell characters will shed light on the shell-based taxonomy. This study aims to estimate the phylogenetic relationship between Geotrochus and Trochomorpha species in Sabah based in two mitochondrial genes (COI, 16S) and one nuclear gene (ITS) and also to examine the influence of temperature, elevation and annual precipitation on the coarseness of shell upper surface sculpture and shell sizes of the species of both genera. Besides, we also investigated the phylogenetic signal of the shell characters. The phylogenetic analysis showed that Geotrochus and Trochomorpha species are not reciprocally monophyletic. The phylogenetic signal test suggested that shell size and upper surface sculpture are homoplastic, and these shell traits are strongly influenced by elevation and annual precipitation, particularly at the cloud zone of Mount Kinabalu. The highland species of both genera have a coarser shell surface than lowland species. The shell and aperture width decrease with increasing elevation and annual precipitation. In the view of finding above, the current taxonomy of Geotrochus and Trochmorpha in this region and elsewhere that based on shell characters need to be revised with sufficient specimens throughout the distribution range of the two genera. 
1 A molecular phylogeny of Geotrochus and

2 Trochomorpha species (Gastropoda:

3 Trochomorphidae) in Sabah, Malaysia reveals

4 convergent evolution of shell morphology driven by

5 environmental influences

6

7

8

9

10

11

12

13

14

15

16

17

18

19

20

21

22

23

24

25

26

27

28

29

30

31

32

33

34

35

36

37

Zi-Yuan Chang, Thor-Seng Liew

Institute for Tropical Biology and Conservation, Universiti Malaysia Sabah, Jalan UMS, 88450

Kota Kinabalu, Sabah

Corresponding Author:

Thor-Seng Liew

Institute for Tropical Biology and Conservation, Universiti Malaysia Sabah, Jalan UMS, 88450

Kota Kinabalu, Sabah

Email address: thorsengliew@gmail.com

\section{Abstract}

There are currently eleven Geotrochus and four Trochomorpha species in Sabah. The primary diagnostic character that separates the two genera is the intensity of sculpture on the shell upper surface. All Trochomorpha species have a coarse nodular sculpture while Geotrochus species has a non-nodular sculpture or smooth shell. However, it is known that shell characters are often evolutionary labile with high plasticity in response to environmental factors. Hence, identifying the phylogenetic and ecological determinants for the shell characters will shed light on the shellbased taxonomy. This study aims to estimate the phylogenetic relationship between Geotrochus and Trochomorpha species in Sabah based in two mitochondrial genes (COI, 16S) and one nuclear gene (ITS) and also to examine the influence of temperature, elevation and annual precipitation on the coarseness of shell upper surface sculpture and shell sizes of the species of both genera. Besides, we also investigated the phylogenetic signal of the shell characters. The phylogenetic analysis showed that Geotrochus and Trochomorpha species are not reciprocally monophyletic. The phylogenetic signal test suggested that shell size and upper surface sculpture are homoplastic, and these shell traits are strongly influenced by elevation and annual precipitation, particularly at the cloud zone of Mount Kinabalu. The highland species of both genera have a coarser shell surface than lowland species. The shell and aperture width decrease with increasing elevation and annual precipitation. In the view of finding above, the current taxonomy of Geotrochus and Trochmorpha in this region and elsewhere that based on shell 
characters need to be revised with sufficient specimens throughout the distribution range of the two genera.

\section{Introduction}

Geotrochus and Trochomorpha are two land snail genera that with similar shell forms belonging to the family Trochomorphidae (Fig. 1). The species of the two genera are ground-dwelling snails typically spotted on the understory vegetation and with overlapping distribution ranges in the region of Oceania and Southeast Asia (Additional File 1). A recent revision of both genera reveals a total of eleven Geotrochus species and four Trochomorpha species in Sabah (Vermeulen et al.2015). Trochomorpha species are endemic to montane forest and subalpine forest between 1500 m and 3400 m on Mount Kinabalu and Crocker Range in Sabah, while Geotrochus species are widespread in Sabah occur from lowland forest at sea level to highland until $2400 \mathrm{~m}$ (Table 1; Vermeulen et al., 2015).

Taxonomy of Geotrochus and Trochomorpha in Sabah has been mainly based on shell and anatomical characters (Tillier \& Boucher, 1988; Vermeulen et al., 2015). Trochomorpha rhysa is the first species of Trochomorpha species described from Sabah (Tillier \& Boucher, 1988) from Mount Kinabalu between $3000 \mathrm{~m}$ and $3500 \mathrm{~m}$. This new species was placed under Trochomorpha based on the genitalia and radula characters. After that, more new species of Trochomorpha and Geotrochus were described solely based on the shell characters (Vermeulen et al., 2015). Vermeulen et al. (2015) noted that these species of the two genera have a similar shell, but Trochomorpha species have a coarser nodular sculpture on the upper surface of the shell.

Taxonomy of land snails based on anatomy and shell characters are not without its weakness because many of these characters are evolutionary labile (Pfenninger et al., 1996; Liew et al., 2009; Holznagel et al., 2010; Hyman \& Ponder, 2010; Hirano et al., 2014; Dowle et al., 2015; Köhler \& Criscione, 2015). This open a question to what extent the shell upper surface sculpture is phylogenetically informative in Geotrochus and Trochomorpha as shell surface sculpture is known to evolve rapidly and in parallel or convergently in response to environmental conditions (Pfenninger \& Magnin, 2001; Schilthuizen et al., 2006; Liew et al., 2009). Therefore, it is vital to examine the phylogenetic relationship among Trochomorpha and Geotrochus species and the influences of habitat climatic factors to clarify the taxonomy of the two genera in Sabah as a way forward to improve the taxonomy of the two genera in Oceania and Southeast Asia in general.

Hence, this study aims to estimate the molecular phylogenetic relationship of selected species of Geotrochus and Trochomorpha species in Sabah by using two mitochondrial genes (COI and $16 \mathrm{~S}$ ) and one nuclear gene (ITS-1). After that, we examined the association of the shell size and shell upper surface sculptures with several environmental variables in their habitats. Lastly, the phylogenetic signal of the shell characters was tested. 
78

79

80

81

82

83

84

85

86

87

88

89

90

91

92

93

94

95

96

97

98

99

100

101

102

103

104

105

106

107

108

109

110

111

112

113

114

115

116

117

\section{Materials \& Methods}

\section{Samples}

All the eleven Geotrochus and four Trochomorpha species from Sabah are available in the BORNEENSIS Mollusca collection of Institute of Tropical Biology and Conservation in Universiti Malaysia Sabah. However, not all specimens of the species were suitable for phylogenetic and morphological analysis (Table 1). A total of six Geotrochus species, namely, G. meristotrochus (Vermeulen, Liew \& Schilthuizen, 2015), G. kinabaluensis (Smith, 1895), G. paraguensis (Smith, 1893), G. oedobasis (Vermeulen, Liew \& Schilthuizen, 2015), G. kitteli, (Vermeulen, Liew \& Schilthuizen, 2015), and G. whiteheadi (Smith, 1895); and three

Trochomorpha species, namely, T. haptoderma (Vermeulen, Liew \& Schilthuizen, 2015), $T$. rhysa (Tiller \& Bouchet, 1988), and T. thelecoryphe (Vermeulen, Liew \& Schilthuizen, 2015) were available phylogenetic analysis. For morphological analysis, a total of 155 specimens of eight Geotrochus and three Trochomorpha species with intact shells were chosen to obtain quantitative and qualitative measurements. As there is no good quality specimen in the collection for Trochomorpha trachus (Vermeulen, Liew \& Schilthuizen, 2015), Geotrochus conicoides (Metcalfei, 1851), Geotrochus spilokeiria (Vermeulen, Liew \& Schilthuizen, 2015) and Geotrochus scolops (Vermeulen, Liew \& Schilthuizen, 2015), these species were not included in the present study. Field sampling was approved by the Sabah Parks for Mt.Kinabalu, Tambuyukon, Mahua, Banggi Island and Balambangan Island, and Yayasan Sabah for INIKEA project site, Imbak Canyon and Maliau Basin (Permit: TTS/IP/100-6/2 Jld.7(70), 2018; Maliau Basin TTRP Project No. 228, 2017; and ICCA Expedition 2017).

\section{DNA extraction, amplification and sequencing}

Foot muscle with about two $\mathrm{mm}^{3}$ was excised from the preserved land snails using a sterilised scalpel. Genomic DNA was extracted using DNeasy Blood and Tissue Kit (Qiagen Inc., Hilden, Germany) following the standard procedure of the manual. Each of the two mitochondrial genes fragment was amplified by using primer pair LCO1490 and HCO2198 (Folmer et al., 1994) with an annealing temperature of $54^{\circ} \mathrm{C}$ for $\mathrm{COI}$; and primer pair 16Sbr-L and 16Sbr-H (Palumbi et al., 1991 ) with an annealing temperature of $47^{\circ} \mathrm{C}$ for $16 \mathrm{~S}$. One nuclear gene fragment (ITS-1) were amplified using the primer pair 5.8c 'silkworm' and 18d' fruitfly' (Hillis \& Dixon, 1991) with an annealing temperature of $55^{\circ} \mathrm{C}$. The PCR thermal-cycling profile includes initial denaturation at $94^{\circ} \mathrm{C}$ for $3 \mathrm{~min}$, followed by 35 cycles of denaturation at $94^{\circ} \mathrm{C}$ for $30 \mathrm{~s}$, annealing at a locusspecific temperature for each primer for $45 \mathrm{~s}$, extension at $72^{\circ} \mathrm{C}$ for $1 \mathrm{~min}$ and a final extension at $72^{\circ} \mathrm{C}$ for $5 \mathrm{~min}$. Positive PCR products were then sent to MyTACG Bioscience Enterprise for sequencing by using the forward and reverse primers that were used during PCR.

\section{Sequence alignment and molecular phylogenetic reconstruction}

The resulting forward and reverse sequences were assembled and aligned in Bioedit 7.2.6 (Hall, 1999), and the sequences were deposited in GenBank (Table 2). A total of four DNA sequence 
118 data matrix were made - one for each of the markers (16S, ITS, and COI) and one concatenated 119 data matrix of the three markers. For the data matrixes with one marker, each was tested for 120 molecular substitution model by using ModelFinder (Kalyaanamoorthy et al., 2017) based on the 121 both AIC and BIC that built into IQ-Tree v.1.6.7 (Nguyen et al., 2015; Trifinopoulos et al., 122 2016). However, the COI data matrix was partitioned by codon positions before it was tested for 123 the molecular substitution model.

124

For concatenated data matrix, it was partitioned by markers and codons (16S, ITS-1, first codon positions of COI, second codon positions of COI, and third codon positions of COI). Each of the partitions was tested for molecular evolution via ModelFinder (Kalyaanamoorthy et al., 2017) and partition models (Chernomor, Von Haeseler \& Minh, 2016) based on the both AIC and BIC that built into IQ-Tree v.1.6.7 (Nguyen et al., 2015; Trifinopoulos et al., 2016). For all the analyses, we limited the candidate models to the six models that are available in MrBayes analysis, namely, JC, F81, K80, HKY, SYM and GTR. The phylogenetic analyses were performed based on the best partitioning scheme and substitution model for the respective markers and concatenated data matrix (Additional File 2).

134

Next, we used Bayesian Inference (BI), and Maximum Likelihood (ML) approaches to reconstruct the phylogenetic trees by using MrBayes v3.2.6 (Huelsenbeck \& Ronquist, 2001) and maximum likelihood (ML) method implemented in IQ-Tree v.2.1.1 (Nguyen et al., 2015) respectively for the concatenated data matrix and the data matrix for each of the three genes. The $\mathrm{BI}$ analysis was run for 1000000 generations along four chains with sample frequency set to 100 and a burn-in of 2500 (25\%) (Additional File 3). The phylogenetic trees generated from the two approaches were then viewed and edited using TreeGraph 2.14 (Stöver \& Müller, 2010). Everettia klemmantanica (Dyakiidae) was selected as an outgroup because this species was the sister taxa of the Trochomorphidae (Bouchet et al., 2017).

\section{Phylogenetic signal analysis}

To investigate the influence of phylogeny on the evolution of shell upper surface sculpture and the four quantitative shell traits, the phylogenetic signal of these shell characters were assessed with Pagel's Lambda (Pagel, 1999) and Blomberg's K (Blomberg et al., 2003). The analysis was performed by using "geiger" package (Harmon et al., 2008) and "phytol" package (Revell, 2012) in the environment of RStudio 1.1.4 (RStudio Team, 2015) following the method of Phung et al. (2017) (Additional File 4). We used the phylogenetic tree resulted from Maximum Likelihood (ML) but retained only one tip for each taxon, except for G. paraguensis which two tips were included - one for each of the two paraphyletic clades. For the qualitative shell trait, all the ten tips with nine species in the phylogenetic tree used for the phylogenetic analysis. However, for the quantitative shell traits, the tips of the phylogenetic tree represented by the juvenile specimen (i.e. T. thelecoryphe) were excluded (Additional File 5). 
158 Shell Characters Measurement

159 A total of five primary diagnostic shell characters that were used for delimitation of the species 160 in Geotrochus and Trochomorpha were measured qualitatively and quantitatively (Fig. 2). The 161 types of shell upper surface sculptures for the adult and subadult specimens with at least three 162 whorls were recorded based on the four categories (S1 - S4) of coarseness that are visible at $8 \times$ 163 magnification. Sculpture S1 - Densely placed, more or less regularly spaced radial riblets and 164 between 11-19 spiral threads that form nodes over the radial sculpture; S2 - Raised and distinct 165 radial growth lines and 15 thin spiral threads; S3 - Indistinct radial growth lines and 166 inconspicuous riblets and between 6 - 23 thin or very thin spiral threads; and S4 - Inconspicuous 167 growth lines and between $4-25$ low and thin spiral threads. There are a few species exhibit 168 variability in the shell upper surface sculptures. Thus, the specimens of these species can be categorised into two shell upper surface sculpture types.

170

Also, four quantitative measurements of shell size, namely, shell height (SH), shell width (SW),

172 aperture height $(\mathrm{AH})$ and aperture width (AW) were measured to nearest $0.1 \mathrm{~mm}$ from the photograph of the shell apertural view with the aid of Leica Stereo Microscope M205 (Fig. 2).

174 Although there are other shell characters included in the description of each species by Vermeulen et al. (2005), we only included these five primary diagnostic characters due to two reasons. First, the evolutionary and ecological aspects of these selected characters are better known since the review by Goodfriend (1986) and second, the other shell characters are speciesspecific.

\section{Collection of ecological data}

182 To investigate the correlation between shell size and upper surface sculpture and the environmental variables, we obtained the elevation, annual precipitation and temperature of the location where the specimens were collected. The elevation of the location was extracted from SRTM DEM 30-meter resolution (http://earthexplorer.usgs.gov/), and the annual precipitation and annual average temperature were extracted from global average temperature and annual precipitation layers of 30 arc-seconds $(\sim 1 \mathrm{~km})$ resolution of WorldClim v1.4 database (www.worldclim.org) using point sampling tool of QGIS v2.60 (QGIS Development Team, 2019). As expected, the annual average temperature is confounding with the elevation. Hence, we explored the influence of the elevation and annual precipitation to the shell sizes and shell surface sculptures, as suggested by Goodfriend (1986).

191

\section{Statistical analysis}

For some species, the specimens are relatively uniform in shell upper surface sculpture and belong to one of the four categories of sculpture intensity. In contrast, other species are variable in shell upper surface sculpture and belong to more than one category (Table 1). Hence, we treated a specimen as an observation unit (i.e. replicates) for each of the four categories 
198

199

200

201

202

203

204

205

206

207

208

209

210

211

212

213

214

215

216

217

218

219

220

221

222

223

224

225

226

227

228

229

230

231

232

233

234

235

236

237

regardless of the specimen's species identity. We tested the null hypothesis $\left(\mathrm{H}_{0}\right)$ of there is no difference in the elevation of the habitat among the between the snail with different shell upper surface sculpture intensity. Besides, we also tested the null hypothesis $\left(\mathrm{H}_{0}\right)$ of there is no difference in the annual precipitation of the habitat among the between the snail with different shell upper surface sculpture intensity. As the data was not normally distributed, we performed Kruskal-Wallis tests to test the hypotheses (Kruskal \& Wallis, 1952). Both analyses were performed in RStudio 1.1.4 (RStudio Team, 2015) (Additional File 4).

We examined the collinearity of among the four shell size measurements. The results showed that aperture width (AW) is strongly correlated with shell width (SW) $(r=0.99)$, while the pairwise correlations among the other measurements are weaker with correlation coefficient values (r) range between 0.65 and 0.71 . Hence, only $\mathrm{SH}, \mathrm{SW}$ and $\mathrm{AH}$ measurements were retained for further analysis. All the three measurements were not normally distributed as reveal by Shapiro-Wilk test (Shapiro \& Wilk, 1965). Therefore, Spearman's correlation tests (Spearman, 1904) were employed to examine the relationships between each of the two environmental variables with the three shell measurements.

\section{Results}

\section{Molecular phylogeny of Trochomorpha and Geotrochus species in Sabah}

The final DNA alignment data matrix consists of 34 taxa and 1918 characters (16S: 1-461bps; COI: 462 - 1112; and ITS-1:1113 - 1918). The phylogenetic relationship of Geotrochus and Trochomorpha species of the concatenated dataset was shown in Figure 3 (Additional File 6). Generally, the phylogenetic trees estimated from each of the three genes show the topology as the tree estimated from the concatenated dataset (Additional File 7). Generally, the three trees reconstructed based on the respective genes congruence to the tree that based combined genes, except for the taxa in Clade D. Particularly, G. oedobasis, G. kitteli, and G. whiteheadi that did not form a clade with $T$. rhysa in $16 \mathrm{~S}$ and COI tree. On the other hand, all the taxa in Clade D appear to be polytomy in the ITS tree.

For concatenated DNA data matrix, the analyses of ML and BI yielded a phylogenetic tree with an identical topology that with $>79 \%$ bootstrap values for ML and 1.00 posterior probability values for the four major clades. Both ML and BI analyses showed that Geotrochus and Trochomorpha species are not monophyletic. Geotrochus kitteli is the sister taxon to Trochomorpha rhysa (Clade D), and T. thelecoryphe is nested in the T. haptoderma (Clade A). Geotrochus paraguensis from Banggi and Balambangan Island is paraphyletic with $G$. kinabaluensis (Clade C). Clade B contained G. meristotrochus.

\section{Evidence for limited phylogenetic signal}

The results from these two approaches showed that the shell height, shell width, aperture height and aperture width of Geotrochus and Trochomorpha considered in this study did not show 
238 significant phylogenetic signal. Besides, the shell upper surface sculptures appear as homoplasy 239 character $(\mathrm{p}>0.05)$ (Fig. 4 and Table 3).

240

241

242

Association between shell morphology and environmental variables

243 The Geotrochus and Trochomorpha species that have coarser shell surface sculpture (i.e. Type $\mathrm{S} 1$ and S2) tend to occupy habitats at higher elevation (above $2000 \mathrm{~m}$ ) (Kruskal-Wallis $\mathrm{X}^{2}=$ $118.36, \mathrm{df}=3, \mathrm{p}<0.0001$ ) and annual precipitation between $2400 \mathrm{~mm}$ and $2500 \mathrm{~mm}$ (KruskalWallis $\mathrm{X}^{2}=70.29$, df $\left.=3, \mathrm{p}<0.0001\right)$, Fig. 5, Additional File 8). Shell width was negatively correlated with elevation $\left(\mathrm{r}_{\mathrm{s}}=-0.42, \mathrm{p}<0.0001\right)$ and with annual precipitation $\left(\mathrm{r}_{\mathrm{s}}=-0.41, \mathrm{p}<\right.$ $0.0001)$ (Fig. 6). On the other hand, shell height $\left(r_{s}=-0.14, p>0.2\right)$ and aperture height $\left(r_{s}=\right.$ $-0.02, p>0.9)$ were neither correlated with elevation nor annual precipitation $\left(r_{s}=-0.11, p>\right.$

250

251

252 $\left.0.3 ; \mathrm{r}_{\mathrm{s}}=-0.05, \mathrm{p}>0.6\right)$.

253

254

255

256

257

258

259

260

261

262

263

264

265

266

267

268

269

270

271

272

273

274

275

276

\section{Discussion}

\section{Phylogeny of Geotrochus and Trochomorpha and its implication to taxonomy}

The phylogenetic analysis showed that Geotrochus and Trochomorpha are not reciprocally monophyletic (Fig. 3). This result is contrary to the current taxonomy of the two genera that was based on the shell characters, especially the shell upper surface sculpture. The confusing taxonomy of the two genera goes back to the description of Geotrochus by van Hasselt (1823, but published in 1824) based on the specimens from Java Island, Indonesia, and the description of Trochomorpha by Albers (1850) based on several Geotrochus-like species from Southeast Asia and Pacific Islands. After that, von Martens (1867) questioned the validity of the description of the genus Geotrochus by van Hasselt (1823, published in 1824) as there is no type assigned to the genus. Hence, von Martens (1867) concluded that the Geotrochus is morphologically similar to Trochomorpha, and he used Trochomorpha instead of Geotrochus as a valid genus for the land snails from Borneo. Later, Issel (1874) used only Trochomorpha for the species recorded in Borneo with no mention of Geotrochus at all. Until the year 1935, Pilsbry (1935) validated the genus Geotrochus based on the Opinions no. 46 rendered by the International Commission on Zoological Nomenclature. Solem (1964) used only Geotrochus for the checklist of land snails in Sabah.

The first detailed shell and anatomical description of the species of the two genera in Sabah were done by Tillier \& Bouchet (1988) based on T. rhysa from Mount Kinabalu. Although the shell morphology, genitalia character and radula were described in detail, there was no comparison made to the known Geotrochus species or Trochomorpha species from other regions. In fact, Geotrochus was not mentioned at all in Tillier \& Bouchet (1988). The first comprehensive revision on Geotrochus and Trochomorpha is by Vermeulen et al. (2015) for the species in Sabah based on the shell morphology. There were four Trochomorpha species, of which three 
277 were new, and 11 Geotrochus, of which six were new were included in the revision (Vermeulen

278 et al., 2015).

279

280

281

282

283

284

285

286

287

288

289

290

291

292

293

294

295

296

297

298

299

300

301

302

303

304

305

306

307

308

309

310

311

312

313

314

315

316

The taxonomy history of the two genera in Sabah that lead to their confusing taxonomy is not merely an isolated case but reflects the taxonomy problem of the two genera on a large scale. The two genera have been used interchangeably as seen in the records of the two genera in the museum worldwide (Additional File 1). As revealed by the GBIF data, there is a large extent of the overlapping in the distribution ranges of the two genera. This pattern could represent a real situation or could be resulted from the misidentification of the species or genera given the fact that the shells of the species in the two genera are very similar. Schileyko (2002a, 2002b) recognised current taxonomy of Trochomorpha is still unresolved, and he placed Trochomorpha in the Family Trochomorphidae whereas Geotrochus in the Family Helicarionidae.

Our results indicate that more comprehensive taxonomy study on Trochomorpha and Geotrochus are needed, not only for the Sabah taxa but for the entire distribution ranges of the two genera. However, the fact that $T$. rhysa is more genetically closely related to the Geotrochus species implies that its putative taxonomy position was likely misled by the parallelism in genital character as documented occasionally occurred in other groups of land snails (e.g. Davison et al., 2005; Hirano et al., 2014). Moreover, the coarse nodular upper surface sculpture was also taxonomically uninformative as the shell character has found evolved independently in this study.

Regarding taxonomy at the species level, this study confirmed the existence of the eight genetically distinct species classified by Vermeulen et al. (2015), except $T$. thelecoryphe and $T$. haptoderma. The two Trochomorpha species are very similar in the shell, but T. thelecoryphe has a flatter spire than T. haptoderma (Vermeulen et al., 2015). It is possible the type specimen of T. thelecoryphe in Vermeulen et al. (2015) was a juvenile shell. Hence, more good condition specimens are needed for further clarification in a future study.

\section{Evolution of shell surface sculpture coarseness and shell sizes of Geotrochus and} Trochomorpha

Polyphyly of the genus Trochomorpha indicated that the diagnostic shell upper surface sculpture is a homoplasy character. Our results show that environments of the habitat influence the shell characters, and phylogenetic closely related species do not tend to resemble each other in the shell size and shell upper surface sculpture. Hence, these shell traits of Geotrochus and Trochomorpha are evolutionary labile that are not suitable to be served as diagnostic characters at the genus level.

The convergence of the shell traits is instead a common phenomenon among land snails that occupying similar ecological niches (Emberton, 1995; Phung et al., 2017). The physical shell is 
317 deemed to be the by-product of adaptation to their environmental attributes (Goodfriend, 1986; 318 Baur \& Raboud, 1988; Pfenninger et al., 2005; Proćków et al., 2017; Proćków et al., 2018; but

319

320

321

322

323

324

325

326

327

328

329

330

331

332

333

334

335

336

337

338

339

340

341

342

343

344

345

346

347

348

349

350

351

352

353

354

355 see Gittenberger, 1991; Fehér et a, 2018 for non-adaptive radiation). The rough surface of the shell helps land snail live with excessive water or moisture in their habitats. For example, ribbed shells retain more water on the shell surface (Giokas et al., 2014); hairy shells increase the snails' adherence wet surface of the plants in a more humid high-elevated area (Pfenninger et al., 2005; Proćków et al., 2018, but see Shyydka et al., 2019); and coarser granular-like surface sculptures on shell help in reducing the water retention on the surface (Nosonovsky \& Bhushan, 2008; Maeda et al., 2019). Besides, rough shells of other few ground-dwelling land snail species are known to be covered with soil that acts as camouflage (Páll-Gergely et al. 2015). From our field observation, we have not observed a shell of the living snail that is covered by soils or other materials. Hence, we suggest that the coarser shell surface helps Trochomorpha and Geotrochus species at highland elevation habitat dwell through fallen wet leaves by reducing the adhesiveness to its surrounding.

As can be seen from the records of the specimens and analysis (Table 1, Fig. 5), the snails with the coarser surface (i.e. S1 and S2) occur above $1500 \mathrm{~m}$ and more commonly above $2000 \mathrm{~m}$. The abrupt transition of the shell surface is unlikely caused by temperature as the temperature generally decreases with increasing elevation (Whitmore 1975; Kitayama 1992, 1994). The occurrence of snails with a coarser shell upper surface (i.e. S1 and S2) at the area with relatively higher annual precipitation. Interestingly, these areas with relatively higher annual precipitation are also located at a higher elevation $(>1500 \mathrm{~m})$.

In addition to rainfall, a substantial amount of precipitation may be added by horizontal rain in the cloud zone (Kitayama, 1992, 1994, 1998) or cloudy mossy forest (Frahm et al., 1996) between $2000 \mathrm{~m}$ and $2800 \mathrm{~m}$. The habitat at this middle slope cloud zone with the increase in water surplus increased from $27 \%$ at $800 \mathrm{~m}$ to $70 \%$ at $2100 \mathrm{~m}$ (Kitayama, 1994, 1998). The species that predominantly with shell surface type S1 and S2 are endemic to Mount Kinabalu, namely, T. haptoderma, T. rhysa, T. thelecoryphe, and G. kitteli that are common above $2000 \mathrm{~m}$ on the mountain.

The relationships between shell size and two significant environmental variables, namely, elevation and precipitation, are well documented (Goodfriend, 1986; Baur \& Raboud, 1988; Pfenninger \& Magnin, 2001; Glass \& Darby, 2009; Anderson et al., 2007; Proćków et al., 2017). Our results show that the shell width and aperture width of the two genera are negatively correlated with elevation and annual precipitation. As the temperature is confounding with elevation, it also means that the shell size of the species in both genera follows converse Bergmann's rule (Baur \& Raboud, 1988; Anderson et al., 2007; Proćków et al., 2017). It was hypothesised that the colder environment induces highland land snail to reach sexual maturity 
356

357

358

359

360

361

362

363

364

365

366

367

368

369

370

371

372

373

374

375

376

377

378

379

380

381

382

383

384

385

386

387

388

389

390

391

392

393

394 395

faster than those living in the warmer area. Hence, shells of the highland land snails are often smaller as the growth of the land snails is limited after maturity (Proćków et al., 2017).

It is known that there is a positive relationship between high precipitation and shell size of land snails because humid habitat promotes the growth and expansion rate of shell whorls (Goodfriend, 1986). However, this may not be the case for montane species (Goodfriend, 1986; Proćków et al., 2017). Our results show that Geotrochus and Trochomorpha species from sites with lower annual precipitation have a larger shell size. Although there is a statistically significant difference in the annual precipitation, we suggest that the precipitation per se might not be the only factor as the species of S1 and S2 that occur above $1500 \mathrm{~m}$ on the Mount Kinabalu are also experiencing horizontal precipitation resulted from the Middle slope wet cloud zone on Mount Kinabalu.

The negative correlation could probably due to the favourable effect of moisture on shell size has been compensated by the lower temperature on the high elevation that generally has a negative effect on shell size (Goodfriend, 1986, Baur \& Raboud, 1988, Anderson et al., 2007). Besides, decreasing in aperture size with the altitudinal gradient has generally been interpreted as an adaptation to the lower humidity at the lower elevational area (Goodfriend, 1986) as smaller apertures tend to lose proportionately more water per unit aperture area (Goodfriend, 1986).

\section{Conclusions}

This study presents the first molecular phylogeny study on the genus Geotrochus and Trochomorpha. The phenotypically identified Sabah Geotrochus and Trochomorpha species do not congruent with the phylogenetic relationships. This incongruency is due to the homoplasy of upper surface sculpture which is used as the diagnostic character of the two genera. The coarser shell character may be an adaptation of the land snails to highland habitat with a more humid condition in the area. Besides, species at the lower elevation habitat tend to has a smaller shell. From the finding above, we concluded that the upper shell sculpture and shell size could not be used for the delimitation of Sabah Geotrochus and Trochomorpha. Hence, the current taxonomy of the two genera need further revision, and the future attempt should consider more samples that cover the entire distribution of the two genera.

\section{Acknowledgements}

We thank Cornelius Peter for his assistance in molecular work. We also thank Edward Braun, Barna Páll-Gergely, Frank Koehler, and an anonymous reviewer for their constructive comments that improve this manuscript.

\section{References}

Albers, J. C. 1850. Die Heliceen, nach natürlicher Verwandtschaft systematisch geordnet. Berlin. 
396 Anderson, R. P., Lew, D., \& Peterson, A. T. 2003. Evaluating predictive models of species'

397 distributions: criteria for selecting optimal models. Ecological modelling, 162(3), 211-232.

398

399 Baur, B., \& Raboud, C. 1988. Life history of the land snail Arianta arbustorum along an

400 altitudinal gradient. The Journal of Animal Ecology, 71-87.

401

402

Blomberg, S. P., Garland Jr, T., \& Ives, A. R. 2003. Testing for phylogenetic signal in

403

comparative data: behavioral traits are more labile. Evolution, 57(4), 717-745.

404

405

Bouchet, P., Rocroi, J. P., Hausdorf, B., Kaim, A., Kano, Y., Nützel, A., Parkhaev, P., Schrödl, 406 M \& Strong, E. E. 2017. Revised classification, nomenclator and typification of gastropod and

407 monoplacophoran families. Malacologia, 61(1-2), 1-527.

408

409

Chernomor O, Von Haeseler A, Minh BQ. 2016. Terrace aware data structure for phylogenomic

410

411

412 inference from supermatrices. Systematic Biology, 65, 997-1008

Darriba, D., Taboada, G. L., Doallo, R., \& Posada, D. 2012. jModelTest 2: more models, new heuristics and parallel computing. Nature methods, 9(8), 772-772.

414

415

Davison, A., Wade, C. M., Mordan, P. B., \& Chiba, S. 2005. Sex and darts in slugs and snails

416

417

418

419

420

421

422

423

424

425

426

427

428

429

430

431

432

433

434

435

436 (Mollusca: Gastropoda: Stylommatophora). Journal of Zoology, 267(4), 329-338.

Dowle, E. J., Morgan-Richards, M., Brescia, F., \& Trewick, S. A. 2015. Correlation between shell phenotype and local environment suggests a role for natural selection in the evolution of Placostylus snails. Molecular Ecology, 24(16), 4205-4221.

Emberton, K. C. 1995. Sympatric convergence and environmental correlation between two land-snail species. Evolution, 49(3), 469-475.

Folmer, O., Black, M., Hoeh, W., Lutz, R.A., \& Vrijenhoek, R. 1994. DNA primers for amplification of mitochondrial cytochrome c oxidase subunit I from diverse metazoan invertebrates. Molecular Marine Biology and Biotechnology, 3,294-299.

Frahm, J. P., Frey, W., Kürschner, H. \& Menzel, M. 1990. Mosses and liverworts of Mt. Kinabalu. Sabah Parks Trustees. 91 p.

Giokas, S., Páll-Gergely, B., \& Mettouris, O. 2014. Nonrandom variation of morphological traits across environmental gradients in a land snail. Evolutionary Ecology, 28, 323-340.

Gittenberger, E. 1991. What about non-adaptive radiation? Biological Journal of the Linnean Society, 43, 263-272. 
437

438

439

440

441

442

443

444

445

446

447

448

449

450

451

452

453

454

455

456

457

458

459

460

461

462

463

464

465

466

467

468

469

470

471

472

473

474

475

476
Glass, N.H., \& Darby, P.C. 2009. The effect of calcium and pH on Florida apple snail, Pomacea paludosa (Gastropoda: Ampullariidae), shell growth and crush weight. Aquatic Ecology, 43(4), 1085.

Goodfriend, G.A. 1986. Variation in land-snail shell form and size and its causes: a review. Systematic Biology, 35(2), 204-223.

Hall, T.A. 1999. BioEdit: a user-friendly biological sequence alignment editor and analysis program for Windows 95/98/NT. Nucleic Acids Symposium Series, 41, 95-98.

Harmon, L.J., Jason, T.W., Chad, D.B., Richard, E.G., \& Wendell, C. 2008. GEIGER:

investigating evolutionary radiations. Bioinformatics, 24, 129-131.

Hillis, D.M., \& Dixon, M.T. 1991. Ribosomal DNA: Molecular Evolution and Phylogenetic Inference. The Quartely Review of Biology, 66, 411-453.

Hirano, T., Kameda, Y., \& Chiba, S. 2014. Phylogeny of the land snails Bradybaena and Phaeohelix (Pulmonata: Bradybaenidae) in Japan. Journal of Molluscan studies, 80(2), 177-183.

Holznagel, W.E., Colgan, D.J., \& Lydeard, C. 2010. Pulmonate phylogeny based on 28S rRNA gene sequences: A framework for discussing habitat transitions and character transformation. Molecular Phylogenetics and Evolution, 57(3), 1017-1025.

Huelsenbeck, J.P., Ronquist, F.R., Nielsen, R., \& Bollback, J.P. 2001. Bayesian inference of phylogeny and its impact on evolutionary biology. Science, 294, 2310-2314.

Hyman, I. T., \& Ponder, W. F. 2010. A morphological phylogenetic analysis and generic revision of Australian Helicarionidae (Gastropoda: Pulmonata: Stylommatophora), and an assessment of the relationships of the family. Zootaxa, 2462(1), 1-148.

Issel, A. (1874) Molluschi Borneensi. Illustrazione delle specie terrestri e d'acqua dolce raccolte nell'isola di Borneo. Dai Signori G. Doria e O. Beccari. Tipografia del R. Instituto Sordo-Muti, Genova.

Kalyaanamoorthy S, Minh BQ, Wong TKF, Von Haeseler A, Jermiin LS. 2017. ModelFinder: fast model selection for accurate phylogenetic estimates. Nature Methods, 14(6), 587-589

Kessing, B., Croom, H., Martin, A., McIntosh, C., McMillan, W.O., \& Palumbi, S. 1989. The simple fool's guide to PCR. Honolulu: Department of Zoology, University of Hawaii, 1-23.

Peer) reviewing PDF | (2020:02:46300:1:2:NEW 2 Oct 2020) 
477

478 Kitayama, K., 1994. Biophysical conditions of the montane cloud forests of Mount Kinabalu, 479 Sabah, Malaysia. In: Hamilton, L.S., Juvik, J.O., Scatena, F.N. (Eds.), Tropical Montane Cloud 480 Forests. Springer Ecological Studies, vol. 110. Springer, New York, pp. 183-197.

481

482

483

484

485

486

487

488

489

490

491

492

493

494

495

496

497

498

499

500

501

502

503

504

505

506

507

508

509

510

511

512

513

514

515

Kitayama, K., Aiba, S. I., Majalap-Lee, N., \& Ohsawa, M. (1998). Soil nitrogen mineralisation rates of rainforests in a matrix of elevations and geological substrates on Mount Kinabalu, Borneo. Ecological Research, 13(3), 301-312.

Köhler, F., \& Criscione, F. 2015. A molecular phylogeny of camaenid land snails from northwestern Australia unravels widespread homoplasy in morphological characters (Gastropoda, Helicoidea). Molecular Phylogenetics and Evolution, 83, 44-55.

Kruskal, W.H., \& Wallis, W.A. 1952. Use of ranks in one-criterion variance analysis. Journal of the American statistical Association, 47(260), 583-621.

Liew, T. S., Schilthuizen, M., \& Vermeulen, J. J. 2009. Systematic revision of the genus Everettia Godwin-Austen, 1891 (Mollusca: Gastropoda: Dyakiidae) in Sabah, northern Borneo. Zoological Journal of the Linnean Society, 157(3), 515-550.

Maeda, H., Yamagishi, R., Ishida, E. H., \& Kasuga, T. (2019). Wettability and dynamics of water droplet on a snail shell. Journal of colloid and interface science, 547, 111-116.

von Martens, E. C. 1867. Die preussische Expedition nach Ost-Asien: nach amtlichen Quellen. Zoologischer Theil/bearb. von Eduard v. Martens (Vol. 2). Verlag der Königlichen geheimen ober-hofbuchdruckerei (R. v. Decker).

Metcalfe, W. 1851. An enumeration of species recent shells, received by W.J. Hamilton, Esq., from Borneo, in November 1850, with descriptions of the new species. Proceedings of the Zoological Society of London, 1851, 70-74.

Miller, M.A., Pfeiffer, W., \& Schwartz, T. 2010. Creating the CIPRES Science Gateway for inference of large phylogenetic trees. In 2010 gateway computing environments workshop (GCE), 1-8.

Nguyen L-T, Schmidt HA, Von Haeseler A, Minh BQ. 2015. IQ-TREE: a fast and effective stochastic algorithm for estimating maximum likelihood phylogenies. Molecular Biology and Evolution, 32(1), 268-274. 
516 Nosonovsky, M., \& Bhushan, B. 2008. Roughness-induced superhydrophobicity: a way to

517 design non-adhesive surfaces. Journal of Physics: Condensed Matter, 20(22), 225009.

518

519 Pagel M. 1999. The maximum likelihood approach to reconstructing ancestral character

520 states of discrete characters on phylogenies. Systematic Biology, 48(3), 612-622.

521

522 Pfenninger, M., Hrabáková, M., Steinke, D., \& Dèpraz, A. 2005. Why do snails have hairs? A

523 Bayesian inference of character evolution. BMC Evolutionary Biology, 5(1), 59.

524

525 Pfenninger, M., \& Magnin, F. 2001. Phenotypic evolution and hidden speciation in Candidula

526 unifasciata ssp. (Helicellinae, Gastropoda) inferred by $16 \mathrm{~S}$ variation and quantitative shell traits.

527 Molecular Ecology, 10, 2541-2554.

528

529

Pfenninger, M., Bahl, A., \& Streit, B. 1996. Isolation by distance in a population of a small land

530 snail Trochoidea geyeri: evidence from direct and indirect methods. Proceedings of the Royal

531

532

533 Society of London. Series B: Biological Sciences, 263(1374), 1211-1217.

534

Phung, C.C., Heng, P.S., \& Liew, T.S. 2017. Land snails of Leptopoma Pfeiffer, 1847 in Sabah,

535

536

537

538

539 Northern Borneo (Caenogastropoda: Cyclophoridae): an analysis of molecular phylogeny and geographical variations in shell form. PeerJ, 5, p. e3981. https://doi.org/10.7717/peerj.3981

540

541

542

543 Proćków, M., Kuźnik-Kowalska, E., \& Mackiewicz, P. 2017. The Influence of climate on shell

544 variation in Trochulus striolatus (C. Pfeiffer, 1828) (Gastropoda: Hygromiidae) and its

545 implications for subspecies taxonomy. In Annales zoologici (Vol. 67, No. 2, pp. 199-221).

546 Museum and Institute of Zoology, Polish Academy of Sciences.

547

548 QGIS Development Team, 2019. QGIS Geographic Information System. Open Source

549 Geospatial Foundation. URL http://qgis.org.

550

551

R Core Team. 2015. R: a language and environment for statistical computing. Vienna: R

552 Foundation for Statistical Computing. Available at http://www.R-project.org/.

553

554 Revell, L.J. 2012. Phytools: an R package for phylogenetic comparative biology (and other 555 things), Methods in Ecology and Evolution, 3, 217-223. 
556

557 Schileyko, A.A. 2002a. Treatise on Recent Terrestrial Pulmonate Molluscs, Part 8: Punctidae,

558 Helicodiscidae, Discidae, Cystopeltidae, Euconulidae, Trochomorphidae. Ruthenica, Supplement $5592,1035-1163$.

560

561

562

563

564

565

566

567

568

569

570

571

572

573

574

575

576

577

578

579

580

581

582

583

584

585

586

587

588

589

590

591

592

593

594

595

Schileyko, A.A. 2002b. Treatise on Recent Terrestrial Pulmonate Molluscs, Part 9:

Helicarionidae, Gymnarionidae, Rhysotinidae, Ariophantidae. Ruthenica, Supplement 2, 11671302.

Shapiro, S.S. \& Wilk, M.B. 1965. An analysis of variance test for normality (complete samples). Biometrika, 52(3-4), 591-611.

Shvydka, Z., Kovalev, A., \& Gorb, S. N. 2019. The frictional and adhesive properties of the shells of terrestrial hairy snails. Journal of Zoology.

Smith, E. A. 1893. On a small collection of land-shells from Palawan and Balabac, Philippine Islands. Annals and Magazine of Natural History, 11(65), 347-353.

Smith, E. A. 1895. On a collection of land-shells from Sarawak, British North Borneo, Palawan, and other neighboring islands. Proceedings of the Zoological Society of London, 63, 97-127.

Solem, A. 1964. A collection of non-marine mollusks from Sabah. Sabah Society Journal, 11, 140.

Spearman, C. 1904. The proof and measurement of association between two things. American journal of Psychology, 15(1), 72-101.

Stamatakis, A. 2014. RAxML version 8: a tool for phylogenetic analysis and post-analysis of large phylogenies. Bioinformatics, 30(9), 1312-1313.

Stöver, B.C., \& Müller, K.F. 2010. TreeGraph 2: combining and visualising evidence from different phylogenetic analyses. BMC bioinformatics, 11(1), 7.

Tillier, S., \& Bouchet, P. 1988. Land snails from the upper montane zone of Mt. Kinabalu (Sabah,Borneo), with descriptions of new species and genera. Indo-Malayan Zoology, 5, 255293.

Trifinopoulos J, Nguyen LT, Von Haeseler A, Minh BQ. 2016. W-IQ-TREE: a fast online phylogenetic tool for maximum likelihood analysis. Nucleic Acids Research, 44(W1), W232W235

Peer] reviewing PDF | (2020:02:46300:1:2:NEW 2 Oct 2020) 
596

597 Van Hasselt, J. C. 1824. Extrait d'une letter de sur les mollusques de l'île de Java. Bulletin

598 Sciences Naturelles, Paris, 3, 81-87.

599

600 Vermeulen, J. J., Liew, T. S., \& Schilthuizen, M. 2015. Additions to the knowledge of the land 601 snails of Sabah (Malaysia, Borneo), including 48 new species. ZooKeys, 531, 1-139.

602

603 Fehér, Z., Mason, K., Szekeres, M., Haring, E., Bamberger, S., Páll-Gergely, B., \& Sólymos, P. 604 2018. Range-constrained co-occurrence simulation reveals little niche partitioning among 605 rock-dwelling Montenegrina land snails (Gastropoda: Clausiliidae). Journal of 606 biogeography, 45(6), 1444-1457. 


\section{Table $\mathbf{1}$ (on next page)}

The number of specimens of Geotrochus and Trochomorpha species included in the respective phylogenetic analysis and shell morphological analysis in this study. 


\begin{tabular}{|c|c|c|c|c|c|c|c|}
\hline \multirow[t]{2}{*}{ Species } & \multirow[t]{2}{*}{$\begin{array}{c}\text { Specimens for } \\
\text { phylogenetic } \\
\text { analysis a }\end{array}$} & \multirow[t]{2}{*}{$\begin{array}{c}\text { Quantitat } \\
\text { ive shell } \\
\text { traits }{ }^{b}\end{array}$} & \multicolumn{4}{|c|}{$\begin{array}{c}\text { Upper shell sculpture } \\
\text { type }^{c}\end{array}$} & \multirow[t]{2}{*}{ Elevational range } \\
\hline & & & S1 & S2 & $\mathbf{S 3}$ & S4 & \\
\hline $\begin{array}{l}\text { Geotrochus conicoides } \\
\text { (Metcalfe, 1851) }\end{array}$ & NA & NA & NA & NA & NA & NA & $63 \mathrm{~m}-363 \mathrm{~m}$ \\
\hline $\begin{array}{l}\text { Geotrochus kinabaluensis } \\
\text { (E.A. Smith, 1895) }\end{array}$ & 2 & 4 & - & - & 3 & 1 & $16 \mathrm{~m}-2001 \mathrm{~m}$ \\
\hline $\begin{array}{l}\text { Geotrochus kitteli } \\
\text { Vermeulen, Liew \& Schilthuizen, } 2015\end{array}$ & 1 & 2 & - & 4 & - & - & $1563 \mathrm{~m}-2376 \mathrm{~m}$ \\
\hline $\begin{array}{l}\text { Geotrochus labuanensis } \\
\text { (Pfeiffer, 1863) }\end{array}$ & NA & 16 & - & - & 14 & 2 & $1 \mathrm{~m}-1494 \mathrm{~m}$ \\
\hline $\begin{array}{l}\text { Geotrochus meristotrochus } \\
\text { Vermeulen, Liew \& Schilthuizen, } 2015\end{array}$ & 5 & 27 & - & - & 21 & 6 & $9 m-1680 m$ \\
\hline $\begin{array}{l}\text { Geotrochus oedobasis } \\
\text { Vermeulen, Liew \& Schilthuizen, } 2015\end{array}$ & 3 & 6 & - & 1 & 5 & - & $260 \mathrm{~m}-2291 \mathrm{~m}$ \\
\hline $\begin{array}{l}\text { Geotrochus paraguensis } \\
\text { (E.A. Smith, 1893) }\end{array}$ & 8 & 10 & - & - & 9 & 1 & $1 \mathrm{~m}-756 \mathrm{~m}$ \\
\hline $\begin{array}{l}\text { Geotrochus scolops } \\
\text { Vermeulen, Liew \& Schilthuizen, } 2015\end{array}$ & NA & NA & NA & NA & NA & NA & $718 \mathrm{~m}$ \\
\hline $\begin{array}{l}\text { Geotrochus spilokeiria } \\
\text { Vermeulen, Liew \& Schilthuizen, } 2015 \\
\end{array}$ & NA & NA & NA & NA & NA & NA & $1241 \mathrm{~m}$ \\
\hline $\begin{array}{l}\text { Geotrochus subscalaris } \\
\text { Vermeulen, Liew \& Schilthuizen, } 2015\end{array}$ & NA & 10 & - & - & 5 & 5 & $6 m-988 m$ \\
\hline $\begin{array}{l}\text { Geotrochus whiteheadi } \\
\text { (E.A. Smith, 1895) }\end{array}$ & 1 & 1 & - & - & 1 & - & $827 m-2080 m$ \\
\hline $\begin{array}{l}\text { Trochomorpha haptoderma } \\
\text { Vermeulen, Liew \& Schilthuizen, } 2015\end{array}$ & 8 & 7 & 43 & - & - & - & $2055 \mathrm{~m}-3360 \mathrm{~m}$ \\
\hline $\begin{array}{l}\text { Trochomorpha rhysa } \\
\text { Tillier \& Bouchet, } 1988\end{array}$ & 6 & 5 & 26 & - & - & - & $1677 \mathrm{~m}-3263 \mathrm{~m}$ \\
\hline $\begin{array}{l}\text { Trochomorpha thelecoryphe } \\
\text { Vermeulen, Liew \& Schilthuizen, } 2015\end{array}$ & 1 & 0 & 8 & - & - & - & $1990 \mathrm{~m}-2992 \mathrm{~m}$ \\
\hline Trochomorpha trachus & NA & NA & NA & $\mathrm{NA}$ & NA & NA & $1563 \mathrm{~m}-1815 \mathrm{~m}$ \\
\hline
\end{tabular}




\begin{tabular}{|l|l|l|l|l|l|l|l|}
\hline Vermeulen, Liew \& Schilthuizen, 2015 & & & & & & & \\
\hline
\end{tabular}




\section{Notes:}

34 a The details for the specimens and the accession number of the DNA sequences are available in Table 2.

35 b The number of specimens available for shell quantitative traits measurement, namely, shell height, shell width, aperture height, and 36 aperture width. The full dataset is available in Additional File 8.

$37 \mathbf{c}$ The number of specimens available for shell surface sculpture examination, and the variations of the shell sculpture types for 38 Geotrochus and Trochomorpha species. The full dataset is available in Additional File 8.

39 NA: No suitable shell was for the DNA data, shell quantitative traits measurement, or shell surface sculpture examination.

40 -: No specimen of the species belongs to the shell surface sculpture type. 


\section{Table 2 (on next page)}

Species, voucher specimens, location information, and GenBank accession number for the specimens included in the phylogenetic analysis. 


\begin{tabular}{|c|c|c|c|c|c|}
\hline \multirow[b]{2}{*}{$\begin{array}{l}\text { Collection } \\
\text { reference } \\
\text { number a of } \\
\text { the voucher } \\
\text { specimens } \\
\text { (BOR/MOL) }\end{array}$} & \multirow[t]{2}{*}{ Taxon } & \multirow[t]{2}{*}{ Location $^{b}$} & \multicolumn{3}{|l|}{ Sequence $^{\mathrm{c}}$} \\
\hline & & & COI & $16 S$ & ITS-1 \\
\hline 6347 & $\begin{array}{l}\text { Trochomorpha } \\
\text { rhysa }\end{array}$ & $\begin{array}{l}\text { Mount Kinabalu at } \\
3024 \mathrm{~m}\end{array}$ & MK779474 & MK334188 & MK335437 \\
\hline 6350 & $\begin{array}{l}\text { Trochomorpha } \\
\text { rhysa }\end{array}$ & $\begin{array}{l}\text { Mount Kinabalu at } \\
3088 \mathrm{~m}\end{array}$ & MK779475 & MK334190 & MK335439 \\
\hline 6353 & $\begin{array}{l}\text { Trochomorpha } \\
\text { rhysa }\end{array}$ & $\begin{array}{l}\text { Mount Kinabalu at } \\
2944 \mathrm{~m}\end{array}$ & MK779477 & MK334191 & NA \\
\hline 6354 & $\begin{array}{l}\text { Trochomorpha } \\
\text { rhysa }\end{array}$ & $\begin{array}{l}\text { Mount Kinabalu at } \\
2944 \mathrm{~m}\end{array}$ & MK779479 & NA & MK335440 \\
\hline 6407 & $\begin{array}{l}\text { Trochomorpha } \\
\text { rhysa }\end{array}$ & $\begin{array}{l}\text { Mount Kinabalu at } \\
3221 \mathrm{~m}\end{array}$ & MK779478 & MK334195 & MK335444 \\
\hline 6411 & $\begin{array}{l}\text { Trochomorpha } \\
\text { rhysa }\end{array}$ & $\begin{array}{l}\text { Mount Kinabalu at } \\
3119 \mathrm{~m}\end{array}$ & MK779476 & MK334196 & MK335446 \\
\hline 6312 & $\begin{array}{l}\text { Trochomorpha } \\
\text { haptoderma }\end{array}$ & $\begin{array}{l}\text { Mount Kinabalu at } \\
2775 \mathrm{~m}\end{array}$ & NA & MK334185 & MK335433 \\
\hline 6349 & $\begin{array}{l}\text { Trochomorpha } \\
\text { haptoderma }\end{array}$ & $\begin{array}{l}\text { Mount Kinabalu at } \\
2896 \mathrm{~m}\end{array}$ & MK779473 & MK334189 & MK335438 \\
\hline 6356 & $\begin{array}{l}\text { Trochomorpha } \\
\text { haptoderma }\end{array}$ & $\begin{array}{l}\text { Mount Kinabalu at } \\
2800 \mathrm{~m}\end{array}$ & MK779472 & MK334192 & MK335441 \\
\hline 6408 & $\begin{array}{l}\text { Trochomorpha } \\
\text { haptoderma }\end{array}$ & $\begin{array}{l}\text { Mount Kinabalu at } \\
2484 \mathrm{~m}\end{array}$ & MK779471 & NA & NA \\
\hline 6409 & $\begin{array}{l}\text { Trochomorpha } \\
\text { haptoderma }\end{array}$ & $\begin{array}{l}\text { Mount Kinabalu at } \\
2526 \mathrm{~m}\end{array}$ & MK779470 & NA & MK335445 \\
\hline 6412 & $\begin{array}{l}\text { Trochomorpha } \\
\text { haptoderma }\end{array}$ & $\begin{array}{l}\text { Mount Kinabalu at } \\
2500 \mathrm{~m}\end{array}$ & MK779469 & MK334197 & MK335447 \\
\hline 6413 & $\begin{array}{l}\text { Trochomorpha } \\
\text { haptoderma }\end{array}$ & $\begin{array}{l}\text { Mount Kinabalu at } \\
2404 \mathrm{~m}\end{array}$ & MK779468 & NA & MK335448 \\
\hline 6417 & $\begin{array}{l}\text { Trochomorpha } \\
\text { haptoderma }\end{array}$ & $\begin{array}{l}\text { Mount Kinabalu at } \\
2896 \mathrm{~m}\end{array}$ & MK779467 & NA & MK335449 \\
\hline 6335 & $\begin{array}{l}\text { Trochomorpha } \\
\text { thelecoryphe }\end{array}$ & $\begin{array}{l}\text { Mount Kinabalu at } \\
2700 \mathrm{~m}\end{array}$ & MK779480 & NA & MK335434 \\
\hline 6342 & $\begin{array}{l}\text { Geotrochus } \\
\text { oedobasis }\end{array}$ & $\begin{array}{l}\text { Mount Kinabalu at } \\
2100 \mathrm{~m}\end{array}$ & MK779461 & MK334186 & MK335435 \\
\hline 6404 & $\begin{array}{l}\text { Geotrochus } \\
\text { oedobasis }\end{array}$ & $\begin{array}{l}\text { Mount Kinabalu at } \\
2200 \mathrm{~m}\end{array}$ & MK811549 & MK334193 & MK335442 \\
\hline 6343 & $\begin{array}{l}\text { Geotrochus } \\
\text { oedobasis }\end{array}$ & $\begin{array}{l}\text { Mount Tambuyukon } \\
\text { at } 2080 \mathrm{~m}\end{array}$ & MK811548 & NA & NA \\
\hline
\end{tabular}




\begin{tabular}{|c|c|c|c|c|c|}
\hline 6344 & $\begin{array}{l}\text { Geotrochus } \\
\text { whiteheadi }\end{array}$ & $\begin{array}{l}\text { Mount Tambuyukon } \\
\text { at } 2080 \mathrm{~m}\end{array}$ & MK811544 & MK334187 & MK335436 \\
\hline 6406 & $\begin{array}{l}\text { Geotrochus } \\
\text { kitteli }\end{array}$ & $\begin{array}{l}\text { Mount Kinabalu at } \\
2300 \mathrm{~m}\end{array}$ & MK779460 & MK334194 & MK335443 \\
\hline 12670 & $\begin{array}{l}\text { Geotrochus } \\
\text { kinabaluensis }\end{array}$ & $\begin{array}{l}\text { Crocker Range, } \\
\text { Mahua at } 1200 \mathrm{~m}\end{array}$ & MK811543 & NA & MK335450 \\
\hline 13017 & $\begin{array}{l}\text { Geotrochus } \\
\text { kinabaluensis }\end{array}$ & $\begin{array}{l}\text { Crocker Range, } \\
\text { Mahua at } 1200 \mathrm{~m}\end{array}$ & MK811542 & NA & NA \\
\hline 13016 & $\begin{array}{l}\text { Geotrochus } \\
\text { meristotrochus }\end{array}$ & $\begin{array}{l}\text { Tawau, INIKEA site } \\
\text { at } 200 \mathrm{~m}\end{array}$ & MK811545 & MK334198 & MK335451 \\
\hline 13323 & $\begin{array}{l}\text { Geotrochus } \\
\text { meristotrochus }\end{array}$ & $\begin{array}{l}\text { Imbak Canyon } \\
\text { Conservation Area } \\
\text { between } 400 \text { and } 600 \\
\text { m }\end{array}$ & MK811547 & MK334204 & MK335459 \\
\hline 13325 & $\begin{array}{l}\text { Geotrochus } \\
\text { meristotrochus }\end{array}$ & $\begin{array}{l}\text { Imbak Canyon } \\
\text { Conservation Area } \\
\text { between } 400 \text { and } 600 \\
\mathrm{~m}\end{array}$ & MK811546 & MK334205 & MK335460 \\
\hline 13373 & $\begin{array}{l}\text { Geotrochus } \\
\text { meristotrochus }\end{array}$ & $\begin{array}{l}\text { Maliau Basin } \\
\text { Conservation Area } \\
\text { between } 400 \text { and } 600 \\
\mathrm{~m}\end{array}$ & NA & NA & MK335461 \\
\hline 13376 & $\begin{array}{l}\text { Geotrochus } \\
\text { meristotrochus }\end{array}$ & $\begin{array}{l}\text { Maliau basin } \\
\text { Conservation Area } \\
\text { between } 400 \text { and } 600 \\
\text { m }\end{array}$ & NA & NA & MK335462 \\
\hline 13061 & $\begin{array}{l}\text { Geotrochus } \\
\text { paraguensis }\end{array}$ & $\begin{array}{l}\text { Kudat, Banggi Island } \\
\text { between } 50-800 \mathrm{~m}\end{array}$ & MK811550 & MK334199 & MK335452 \\
\hline 13176 & $\begin{array}{l}\text { Geotrochus } \\
\text { paraguensis }\end{array}$ & $\begin{array}{l}\text { Kudat, Banggi Island } \\
\text { between } 50-800 \mathrm{~m}\end{array}$ & MK811552 & MK334200 & MK335454 \\
\hline 13177 & $\begin{array}{l}\text { Geotrochus } \\
\text { paraguensis }\end{array}$ & $\begin{array}{l}\text { Kudat, Banggi Island } \\
\text { between } 50-800 \mathrm{~m}\end{array}$ & MK811551 & MK334201 & MK335455 \\
\hline 13223 & $\begin{array}{l}\text { Geotrochus } \\
\text { paraguensis }\end{array}$ & $\begin{array}{l}\text { Kudat, Banggi Island } \\
\text { between } 50 \text { and } 800 \mathrm{~m}\end{array}$ & MK779464 & MK334202 & MK335456 \\
\hline 13224 & $\begin{array}{l}\text { Geotrochus } \\
\text { paraguensis }\end{array}$ & $\begin{array}{l}\text { Kudat, Banggi Island } \\
\text { between } 50-800 \mathrm{~m}\end{array}$ & MK779465 & NA & MK335457 \\
\hline 13225 & $\begin{array}{l}\text { Geotrochus } \\
\text { paraguensis }\end{array}$ & $\begin{array}{l}\text { Kudat, Banggi Island } \\
\text { between } 50-800 \mathrm{~m}\end{array}$ & MK779463 & MK334203 & MK335458 \\
\hline 13068 & $\begin{array}{l}\text { Geotrochus } \\
\text { paraguensis }\end{array}$ & $\begin{array}{l}\text { Kudat, Balambangan } \\
\text { Island between } 20- \\
100 \mathrm{~m}\end{array}$ & MK779462 & NA & MK335453 \\
\hline 13084 & $\begin{array}{l}\text { Geotrochus } \\
\text { paraguensis }\end{array}$ & $\begin{array}{l}\text { Kudat, Balambangan } \\
\text { Island between } 20- \\
100 \mathrm{~m}\end{array}$ & MK779466 & NA & NA \\
\hline
\end{tabular}




\section{Notes:}

5 a All specimens were deposited at BORNEENSIS reference collection at Universiti Malaysia

6 Sabah.

7 b All specimens were collected from the State of Sabah, Malaysia. The elevation of the

8 specimens collected from the habitats was indicated.

$9{ }^{\mathbf{c}}$ NA: The DNA sequence was not available as the amplification of the gene was not successful. 


\section{Table 3 (on next page)}

Result of the phylogenetic signal test using Pagel's $\lambda$ method and Blomberg's $K$ method. 


\begin{tabular}{|l|l|l|l|l|l|}
\cline { 2 - 6 } 2 & Lambda $(\boldsymbol{\lambda})$ & p-value & K & p-value \\
\cline { 2 - 6 } & Upperl traits & 0.000 & 1 & 1.021 & 0.067 \\
\hline Maximum shell height & 0.638 & 0.565 & 0.954 & 0.108 \\
\hline Maximum shell width & 1.000 & 0.258 & 0.994 & 0.070 \\
\hline Maximum aperture height & 0.000 & 1 & 0.700 & 0.339 \\
\hline Maximum aperture width & 0.855 & 0.456 & 0.895 & 0.124 \\
\hline
\end{tabular}




\section{Figure 1}

The variation of shell forms of 11 Geotrochus species and four Trochomorpha species in Sabah.

(A) G. conicoides (BOL/MOL 2431). (B) G. paraguensis (BOL/MOL 13061). (C) G. kinabaluensis (BOL/MOL 13020). (D) G. labuanensis (BOL/MOL 904). (E) G. oedobasis (BOL/MOL 908). (F) G. subscalaris (BOL/MOL 2430). (G) G. meristotrochus (BOL/MOL 13833). (H) G. whiteheadi (BOL/MOL 4110). (I) G. kitteli (BOL/MOL 4109). (J) G. spilokeiria (image from Vermeulen et al., 2015, CC BY 4.0). (K) G. scolops (image from Vermeulen et al., 2015, CC BY 4.0). (L) T. trachus (BOL/MOL 2959). (M) T. haptoderma (BOL/MOL 6312). (N) T. rhysa (BOL/MOL 3986). (0) T. thelecoryphe (BOL/MOL 6334). 


\section{Geotrochus}

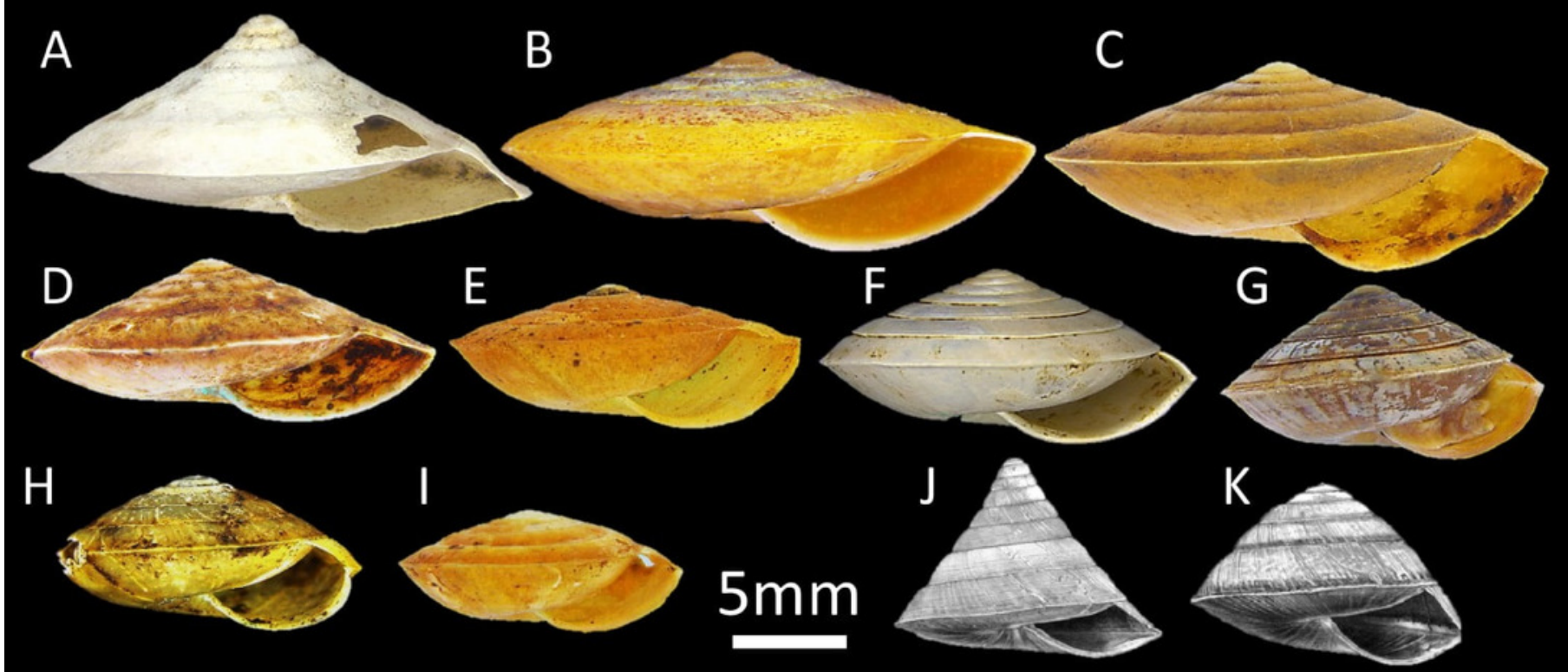

\section{Trochomorpha}
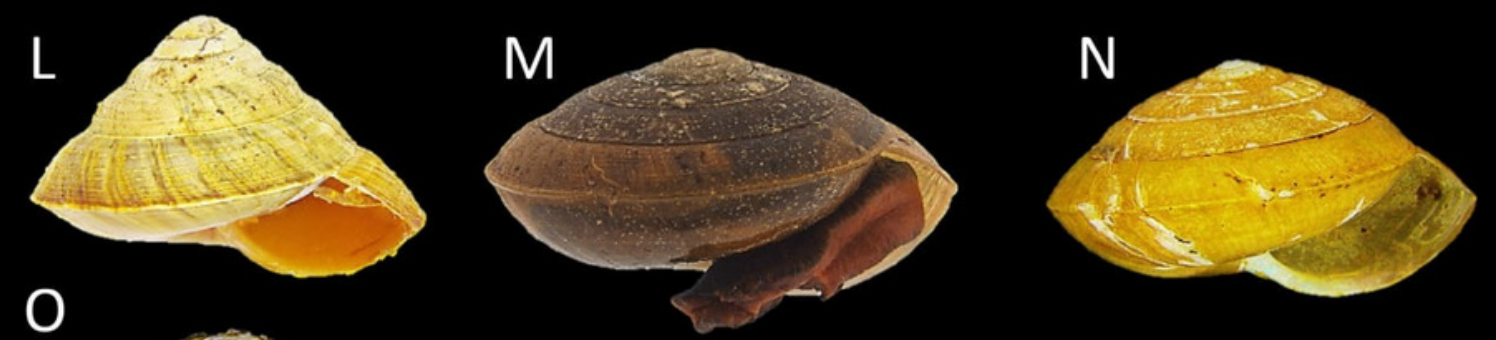

\section{$5 \mathrm{~mm}$}

O

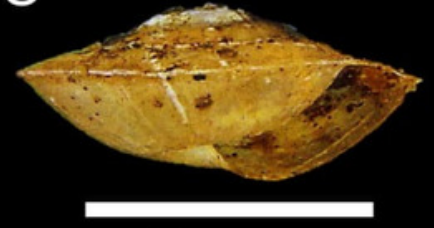

$5 \mathrm{~mm}$ 


\section{Figure 2}

Upper surface sculptures and quantitative shell traits included in this study.

(A) Sculpture with spiral threads form nodes over radial sculpture (BOL/MOL 6312). (B)

Sculpture with raised and distinct radial growth lines and thin spiral threads (BOL/ MOL

6406). (C) Sculpture with indistinct radial growth lines and inconspicuous riblets and thin or

very thin spiral threads (BOL/ MOL 13061). (D) Sculpture with inconspicuous growth lines and

low and thin spiral threads (BOL/ MOL 890). (E) Four quantitative shell measurements: SH,

Shell height; SW, Shell width; AH, Aperture height; and AW, Aperture width. 


\section{Upper surface sculptures}

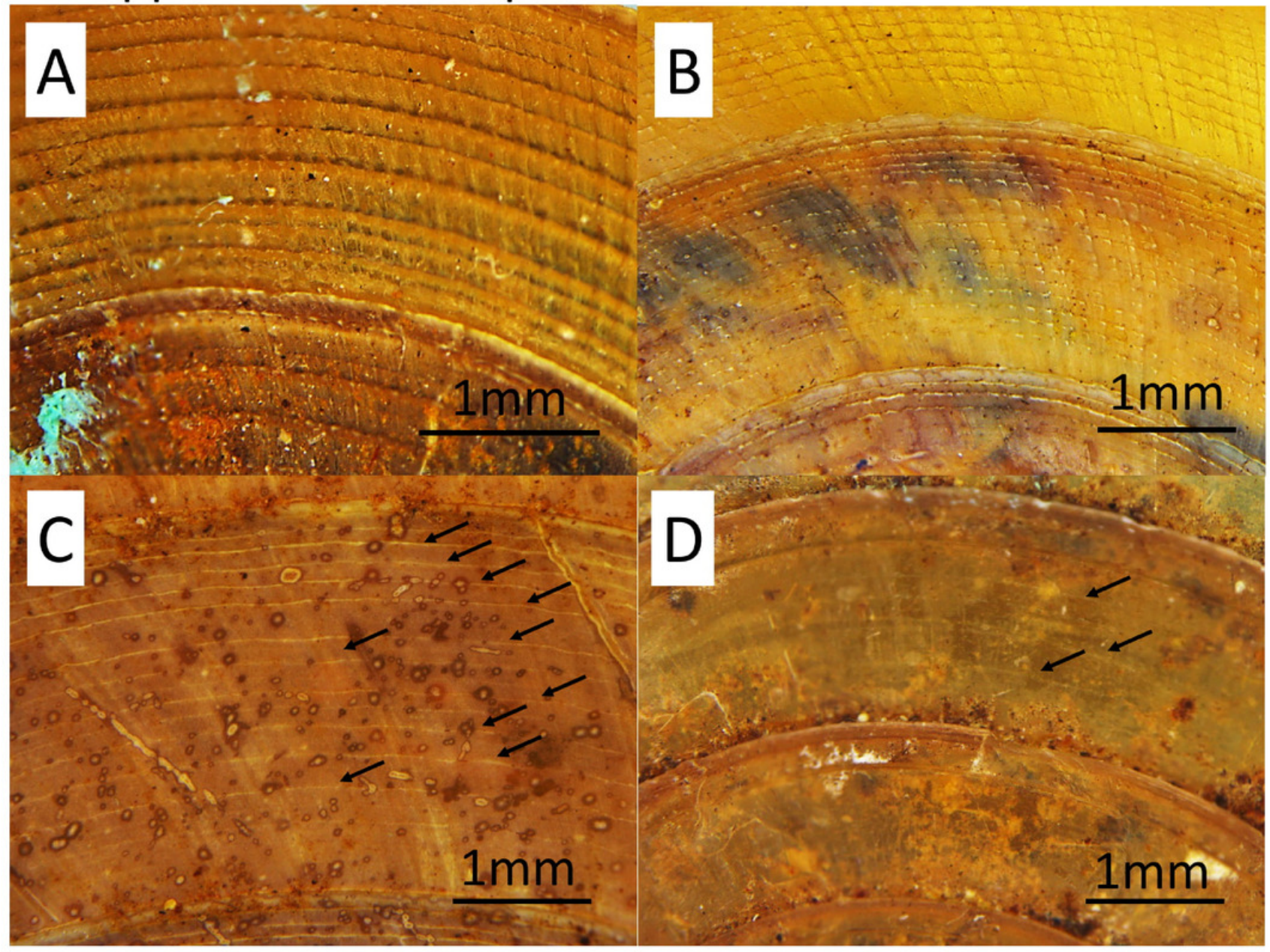

E

$\mathrm{SH}$

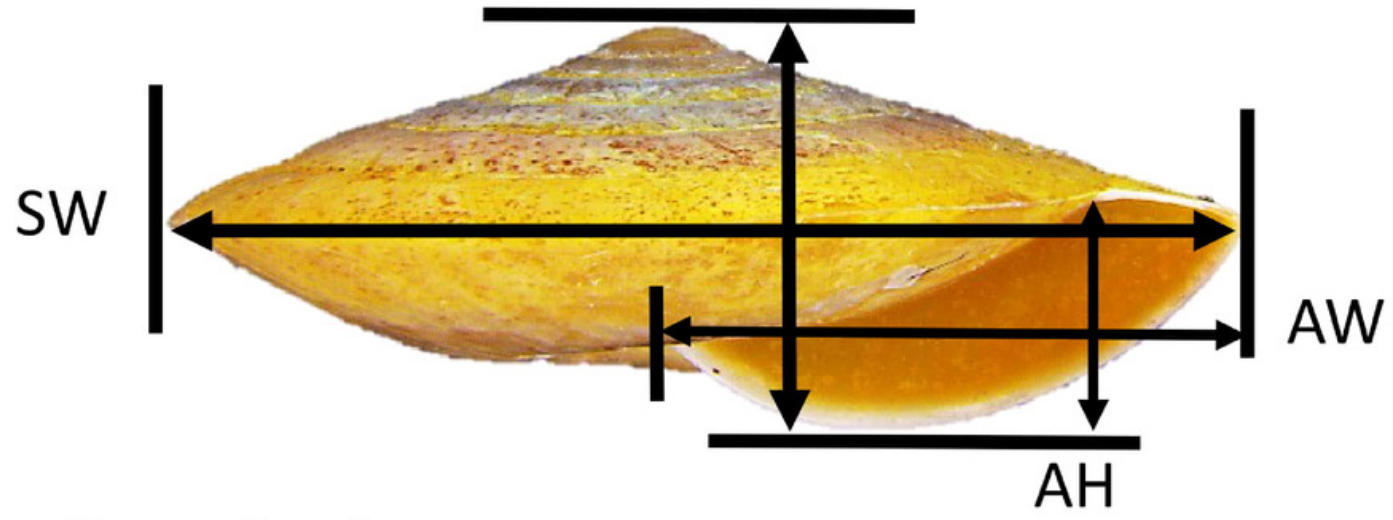

Quantitative measurements 


\section{Figure 3}

Bayesian inference tree of Geotrochus and Trochomorpha spp. based on concatenated dataset of $16 \mathrm{~S}$ rDNA, COI and ITS-1 rooted to Everettia klemmantanica.

The alphabet, A - D, indicate the four major clades. Posterior probability (above the branch) from Bayesian inference and bootstrap support values (below the branch) from maximum likelihood analysis are indicated at the nodes with support values less than 0.7 of PP and $70 \%$ of BS were not shown in the figure. The number annotated in front of the species name was the BORNEENSIS collection number (Table 3). 


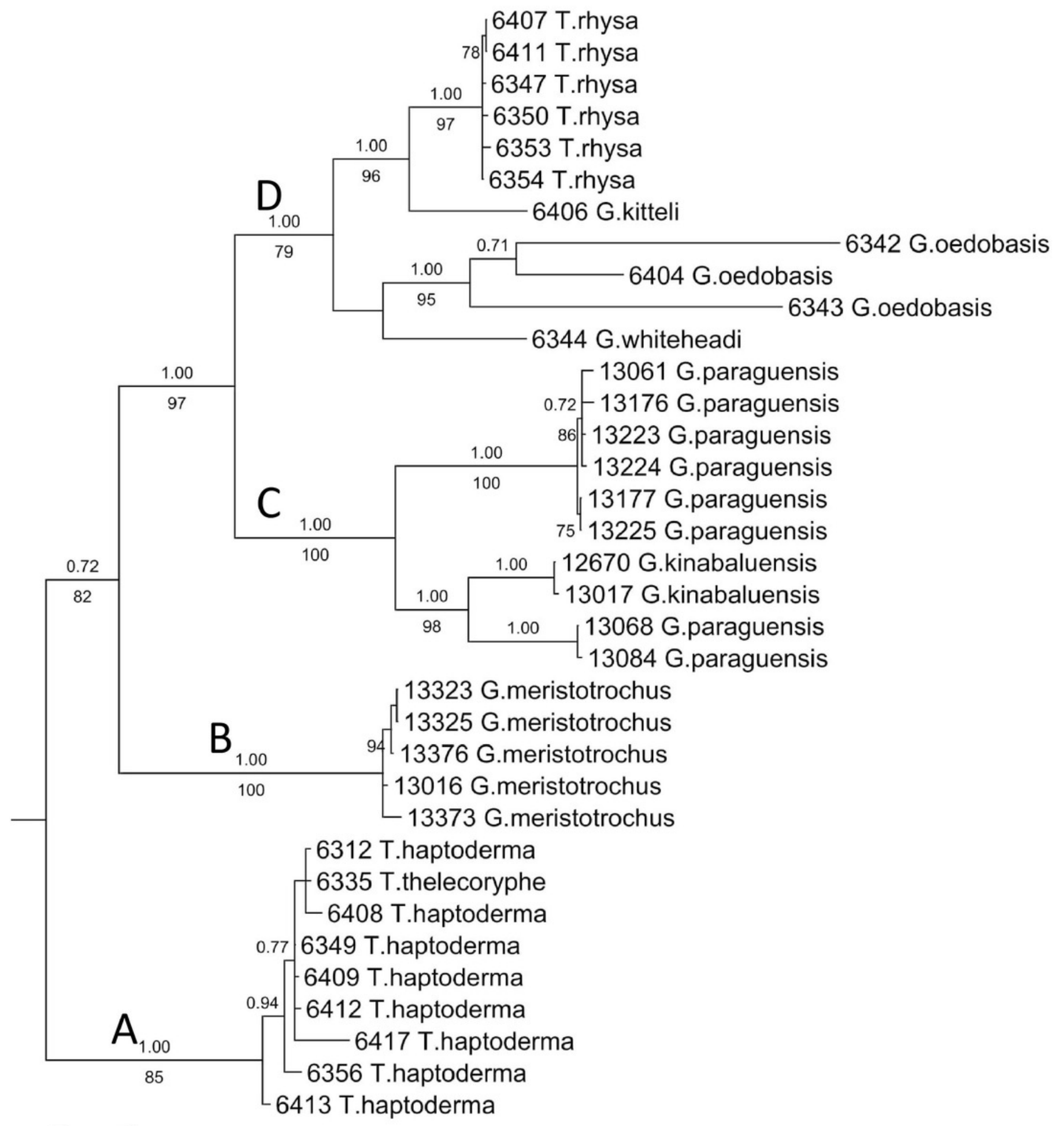

0.02 
Figure 4

Shell upper surface sculpture types and quantitative shell's traits were mapped on to the phylogenetic tree.

The shell upper surface sculpture types were represented by the different colour of the squares; and the four shell quantitative traits: maximum shell height, maximum shell width, maximum aperture height, maximum aperture width were represented by the size of the grey circle. The quantitative traits measurements were not available for $T$. thelecoryphe.

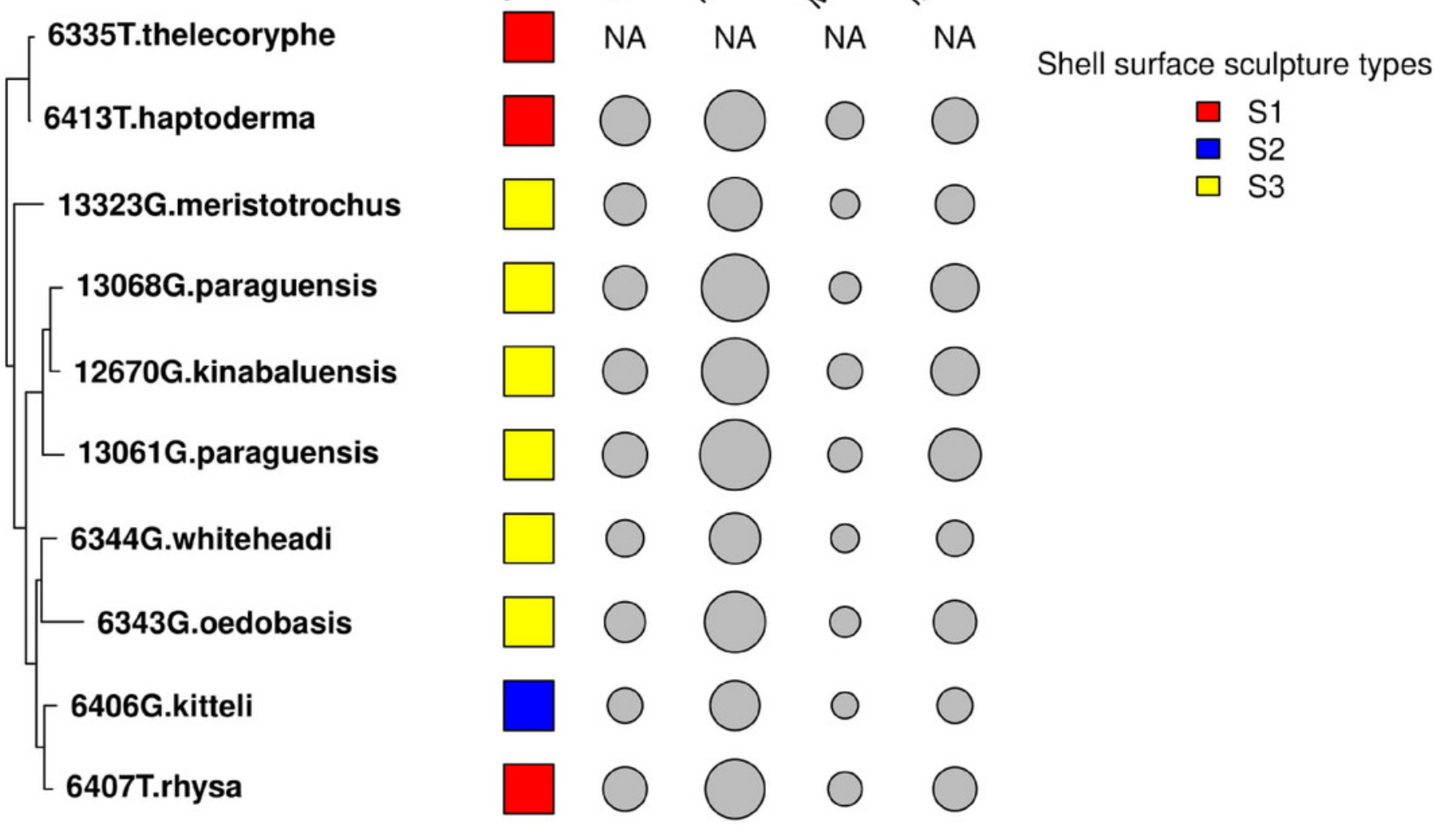




\section{Figure 5}

Boxplots show the differences of the elevation and precipitation of the habitats of the shell with the four shell upper surface sculptures (S1 - S4).

Kruskal-Wallis tests were performed, and the Chi-square values and the p-value of the test were shown in the plot. The alphabets above the boxplot indicate the results of multiple Wilcoxon signed-rank tests posthoc test. Sample sizes for each shell upper surface sculpture types were: S1 ( $n=77)$; S2 $(n=5)$; S3 $(n=58)$; S4 $(n=15)$. (A) Differences of the elevation of the habitats of the shell with the four shell upper surface sculptures. (B) Differences of the annual precipitation of the habitats of the shell with the four shell upper surface sculptures.

A

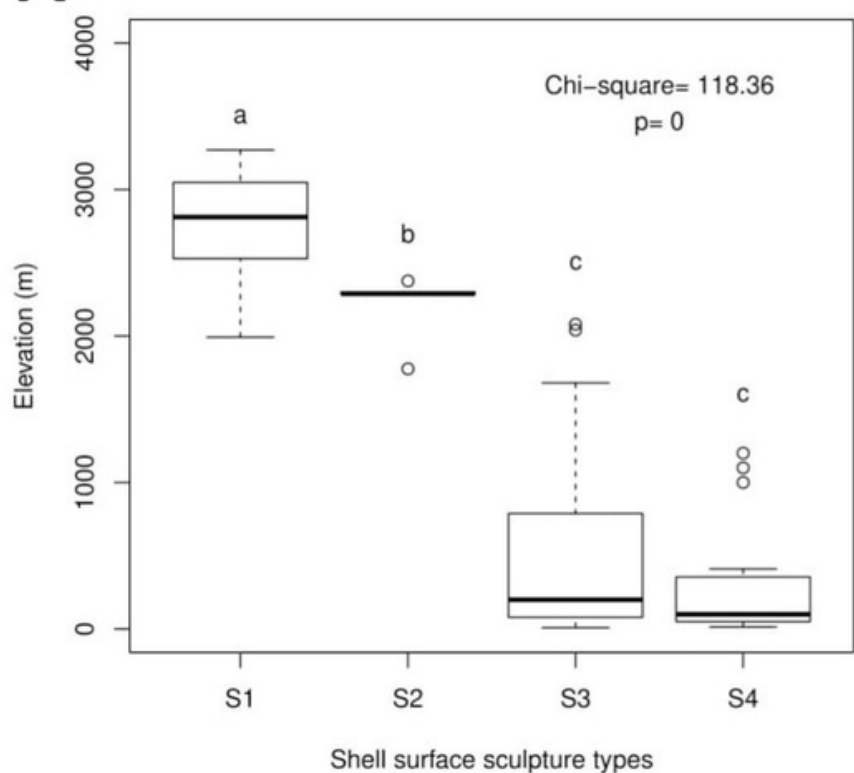

B

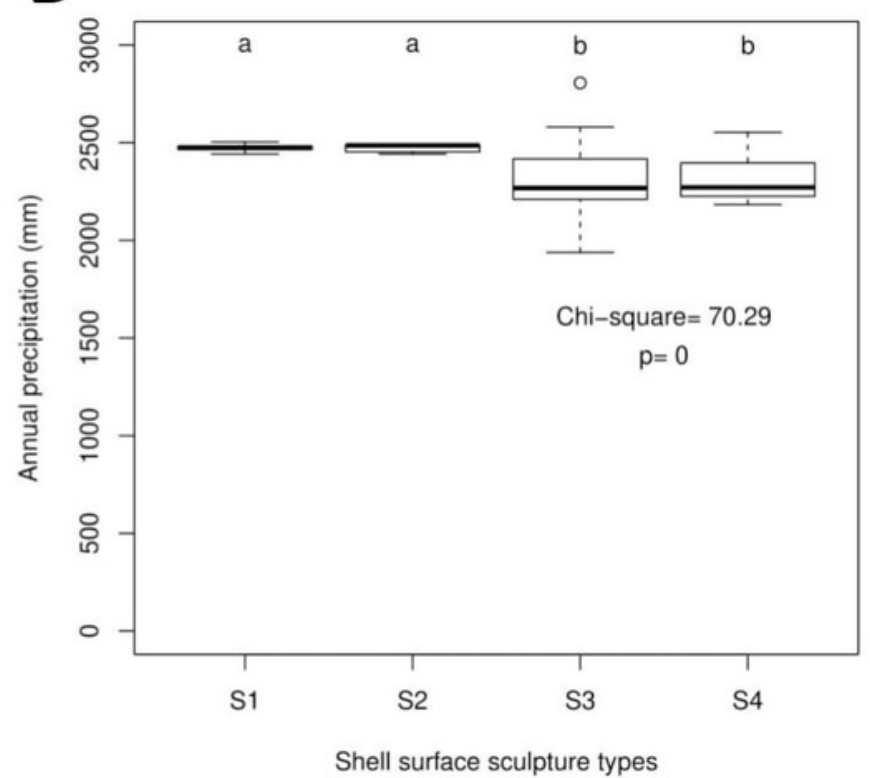




\section{Figure 6}

Correlations between shell quantitative traits (i.e. sizes) and environmental variables (elevation and precipitation).

Spearman correlation tests were performed, and the correlation coefficient values $(r)$ and the $p$-value of the test were shown in the plot, $n=155$. (A) A significant negative correlation between shell width and elevation. (B) A significant negative correlation between shell width and annual precipitation. (C) No significant correlation between shell height and elevation. (D) No significant correlation between shell height and annual precipitation. (E) No significant correlation between aperture height and elevation. (F) No significant correlation between aperture height and annual precipitation. 

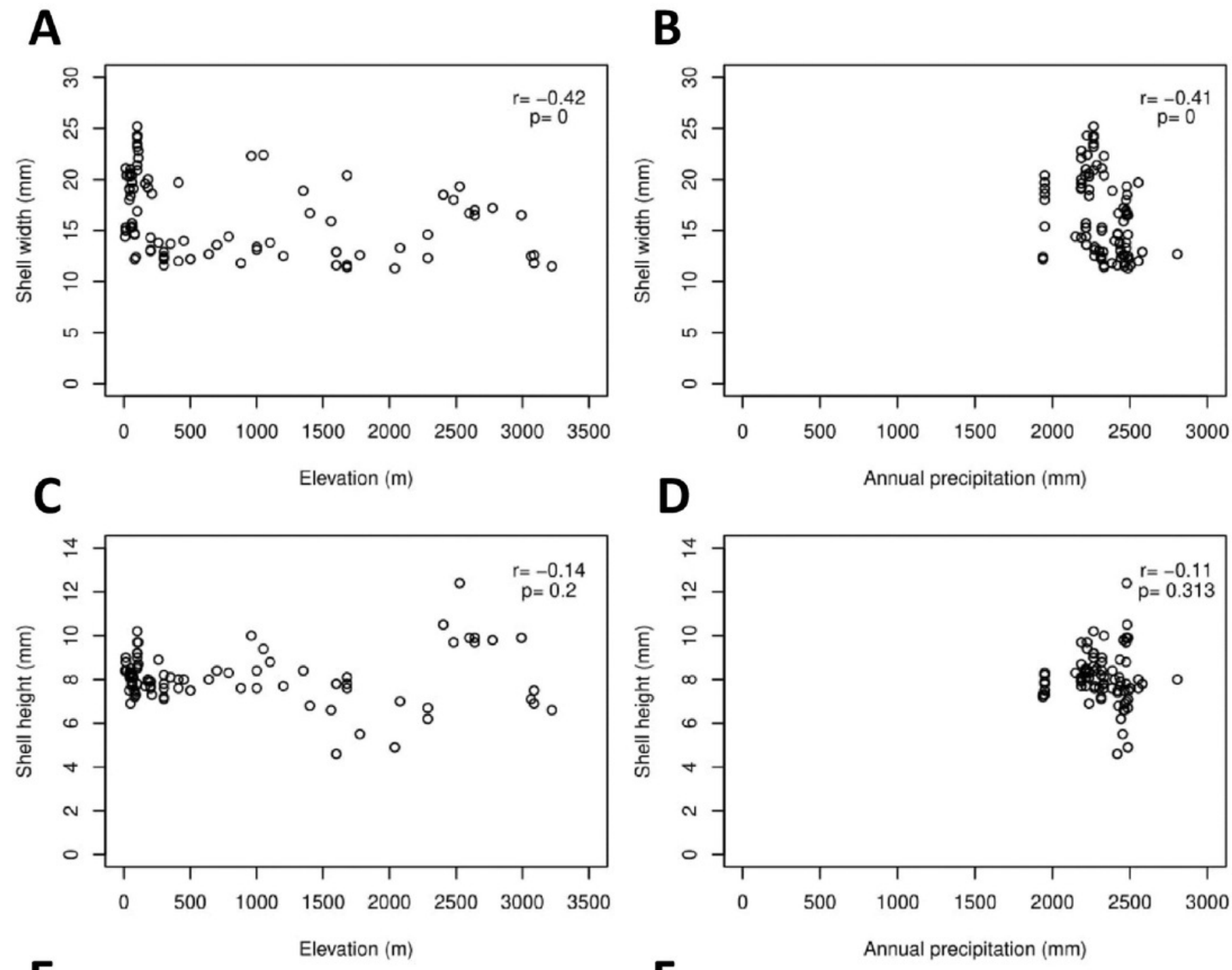

E

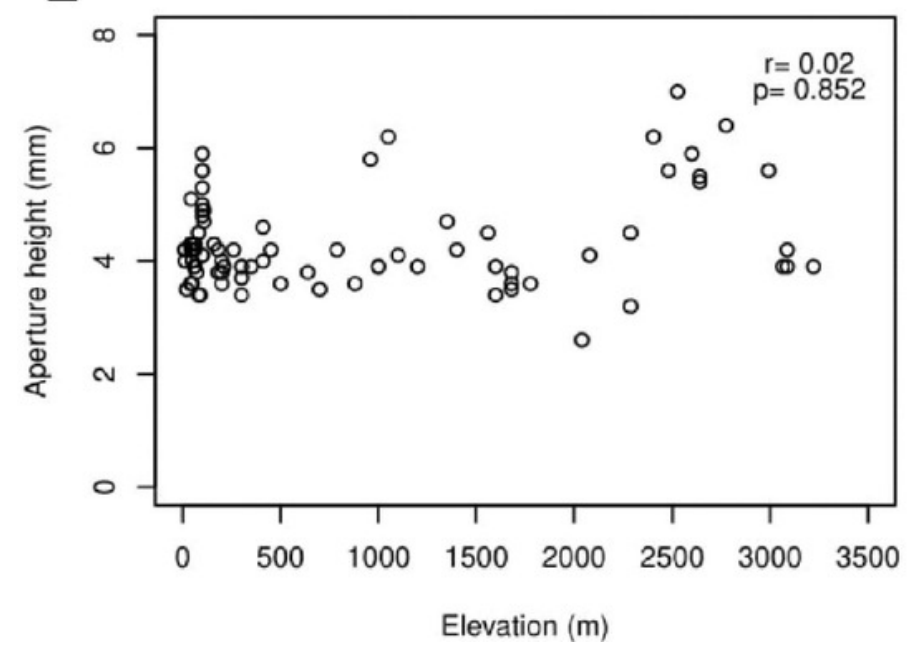

$\mathbf{F}$

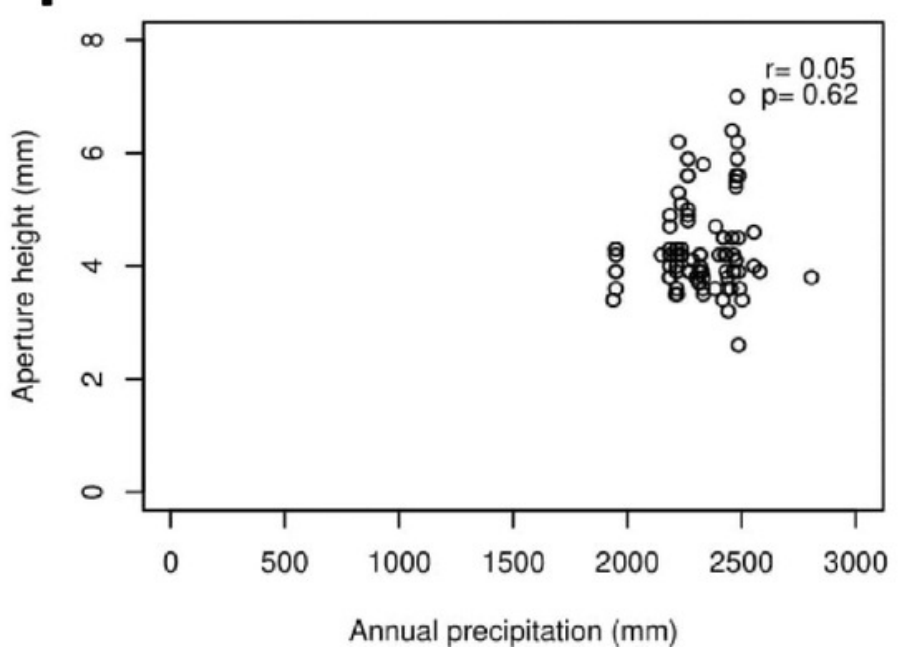

